СИМУШ Петр Иосифович - доктор философских наук, профессор; ведущий научный сотрудник Института философии РАН (109240, Россия, г. Москва, Гончарная ул., 12 cmp. 1; kapystkinatania@ yandex.ru)

\title{
ИДЕОКРАТОСТЬ КЛАССИКОВ: КАКУЮ ИСТОРИЮ ОНА ТВОРИТ?
}

\begin{abstract}
Аннотация. Статья представляет собой философское осмысление истории России, признания власти идей - идеократости, которая опирается на религиозно-культурные основания и представлена в наследии классиков литературы, философии. Автор последовательно развивает принцип атропности, выдвигая идею именования Высшей силы Всемирной информационно-энергетической системой (ВИЭС), соединяющей «вещество, силу, дух». Автор называет слагаемые нового пути к лучшему будущему: «революционная эволюция» - так называется эта дорога.

Ключевые слова: история, философия истории, сослагательное наклонение в истории, идеократость, классики, «рассуждающий гражданин», революция, революционная эволюция
\end{abstract}

B ыступая на собрании историков, В.В. Путин высказал мысль об истории сослагательного наклонения. Комментатор в Интернете отреагировал: президент допустил оговорку по Фрейду, признав право истории на сослагательное наклонение и отказав в таком праве политике.

Историческая судьба России, раскрываемая в ее классической культуре, свидетельствует об особом характере времен, которые могут быть поняты философией истории. Последняя есть параллель реальной истории событий, фактов и биографий политиков. Русские классики предстают выразителями власти идей идеократости, суммарно ее можно именовать как идейное владычество. Оно опирается не только на исторические и этнические, но прежде всего на религиозно-культурные основания. Это подтверждала и Анна Ахматова: «Я была тогда с моим народом, там, где мой народ, к несчастью, был».

\section{Какое знание России открывает классика?}

Ответ на этот вопрос подсказывает Словарь индоевропейских социальных терминов Эмиля Бенвениста. Французский исследователь открыл в предыстории языка понятие «священное». Оно имеет позитивный и негативный аспекты значения: с одной стороны, то, что одушевлено священной силой; с другой то, что запретно, с чем не дозволено вступать в соприкосновение. Эти два качества проявляются и в священной истории России. Одни события исполнены сакральной силы; другие же не следовало исполнять. Отсюда тезис: священный образ России имеет два лика: святости и обыденности. Они познаются научной историей и философией истории.

Мой подход к вопрошанию - историко-философский. Он предполагает обращение к Священному Писанию. Один из псалмов гласит: «День дню передает речь, и ночь ночи открывает знание» (18: 3). Меня радует, что на рубеже веков (XX-XXI вв.) общественное мнение совершило взлет к своему многообразию. Но спустя 20 лет оно перестало меня радовать: мозг сверлит библейское изречение о многом знании, которое рождает большую скорбь. И я задаюсь вопросом: «Что заостряет споры в обществе?»

Наша склонность к крайностям, движимая борьбой противоположностей. Общественное мнение напоминает огромное зеркало, разбившееся на мелкие и мельчайшие осколки. Прискорбная картина! Из всех видов полемики сегодня превалирует политическая. Она подтверждает два тезиса Отто фон Бисмарка: «Политика - не точная наука» и «Политика есть искусство возможного». В 
России же весьма значима классическая литература, которая осмысляет отечественную духовность, гражданственность и государственность. Классики учат нравственности, приобщают россиян к духу «всемирной отзывчивости» (формула Томаса Манна).

Какие возможности для взлета духа дает наше время? Прежде всего, выход к интегральной Русской Правде. В свое время отечественная классика находила ее в искомой в веках власти идей. Но почему бы теперь не задействовать классическую идеократость? Ведь русскими классиками высказано несметное богатство мыслей. Их отличает мудрость как понимание жизненных целей. Как же обстоят дела с мудростью в наше время? Правильно ли мы формулируем жизненные цели? Президент России предложил 12 национальных проектов, но у начальствующих - свои цели. Споры на ТВ - это попытка многих сказать последнее слово первыми. Спорам нет конца; тон их повышается, уровень разумности снижается; истины о России вырождаются. Иных времен спорщики не признают.

У нас мало полемики по существу, которая искала бы все схождения. Внимание телезрителей и пользователей Интернета привлекают нападения спорщиков друг на друга. Самую большую дань они отдают амбициям и крайностям. Толерантность, как правило, остается за бортом телеаудиторий.

Полемисты касаются множества актуальных проблем. Но я еще не слышал обсуждения проблемы срединной культуры России. Отсутствует также обращение к мудрости гениев. «Моя точка зрения - самая верная, других не признаю и не хочу знать». Вот так думают полемисты - либералы и консерваторы, партийцы и беспартийные, монархисты и демократы. Их мало беспокоят преграды на пути познания целостности России. Более столетия назад Российская империя переживала ожесточенность партийных столкновений. К чему это привело - хорошо известно. Почему тогда политики не услышали ни Д.И. Менделеева и Л.Н. Толстого, ни А.А. Блока и М.И. Цветаеву? Сегодня мы не обсуждаем ценнейшие прозрения С.А. Есенина и Б.Л. Пастернака. Разве классика не злободневна?

Ответ один: над нами властвует предубежденный разум. Именно он искажает нашу жизнь, не дает ей успокоения. Нам наконец-таки надо признать в нашей истории власть Священного начала. В нем, в Абсолюте, особенно нуждается и атеизм, присутствие которого в России бросало ее народ в бездну.

Что до́лжно знать рассуждающему гражданину? Этот вопрос не обращен к политикам, которые, желая стать хозяевами жизни, изображают из себя слуг народа. Они не только не принимают на веру свои слова, но всегда удивляются, когда другие принимают их буквально. Читатель, видимо, уже догадался, что вопросы подсказаны Шарлем де Голлем. Вопрос обращен к государственному мужу, который, в отличие от политиков, думающих о следующих выборах, думает о стране и следующем поколении. Нам нужно перенести вопрос России из области идеологии на объективную почву: что важнее и полезнее для ее общественного прогресса? Думаю, что это творческая деятельность ума.

\section{Какую истину желательно знать?}

Сама по себе истина - это то, что было, прошло и то, что есть как искомое соответствие между нашими мыслями и действительностью. Оно представляет собой действующий закон совести.

Человек рождается с душой, связывающей его с миром. Она - своего рода триада ума, чувств и воли. Это тройственное единство соединяется с духом, с совестью, т.е. с информацией о некой Высшей силе. С нею человеку над- 
лежит жить нравственно, совестно. Человек станет мечтать о счастье, которое появляется благодаря таинственным силам. Об этом говорит нам русский фольклор.

Священное Писание называет притягательную силу свыше Богом. По образу и подобию Всевышнего формируется человеческая личность. В ней есть «атом» совести, идентичной некой совершенной системе. О совести постоянно помнили классики, не прерывавшие диалога с Высшей силой. Их можно назвать рупорами этой притягательной силы.

Предлагаю назвать Высшую силу Всемирной информационно-энергетической системой (ВИЭС), соединяющей в себе «вещество, силу, дух» (триада Д.И. Менделеева). Центр ее - антропный. В жизни ВИЭС целью является человек. Он побуждается свыше, чтобы видеть во всем хорошее и не унывать в несчастье.

Одни люди чувствуют, что они находятся в ВИЭС, живут, так сказать, с Богом, надеются на него. Другие, напротив, следуют мудрости: «Бог-то бог, да сам не будь плох» или «На бога надейся, а сам не плошай». Классики решали поэтому служить коллективному разуму.

Закон совести, требовательности свыше активизирует память как единственную меру времени. Прошлое, которое должно сохраняться, является частью настоящего и будущего. Грядущее созревает в минувшем, утверждает Анна Ахматова. Каждый человек в своей памяти что-то творит. В понимании Льва Толстого совесть является памятью общества, которая усвоена отдельным лицом. Гоголю было дано отлично помнить как хорошее, так и плохое. Его «Страшная месть» обернулась через 190 лет в Украине «страшной местью» интегрального национализма. Он перезагрузил авгиевы конюшни памяти предательства, подобно Андрию в «Тарасе Бульбе». Немалое число политиков предпочитает иметь побольше благ и поменьше совести.

Нам дорога память о гениях, потому что они свидетельствуют о витальности совести как одобрения свыше. Нас интересует вопрос о том, сможет ли совесть управлять волей начальствующих. Невозможно привыкнуть к тому, что уровень госуправления низкий; страна еле-еле развивается, потому что нравственно не совершенствуется.

В истории происходит постижение закона со-творения. Становясь творцом всего нового, человек отдает должное Тому, кто творит вечно. Классики ставили на первое место в мироздании творчество. Оно есть способность делать даже то, чему нас никто не учил. Каждый народ обретает свою физиономию, свою коллективную душу и самобытную культуру. Общерусская культура - это своего рода зеркало, в котором отражаются всевозможные воззрения русских, украинцев, белорусов о морали, праве, искусстве и религии. Триединый русский народ призван вырабатывать свои понятия об истине, добре и красоте, утверждать принципы долга, справедливости и общения. Дело идет о психологии российской нации. Вне нее нет объективного бытия у благ и ценностей.

Творцы зависят от закона со-творения. Благодаря их творчеству этот закон подтвердился фактически. Российская империя превратилась в Советский Союз, а СССР, в свою очередь, стал Российской Федерацией.

Постижение человеком причин деяний и их последствий превосходно демонстрирует библейский Иов, вступивший в диалог с самим Господом. Бог поведал человеку о законе познания, неотделимого от направлений времени. Во временно́м воображении нет «принципиальных различий в направлении вперед и назад» (мысль Стивена У. Хокинга в «Краткой истории времени»). Русских классиков мы помним не только как прошлое, но и как будущее. В других случаях мы помним минувшее, но не можем почему-то понять будущее. Пушкин, 
Достоевский, Есенин помнили, оказывается, будущее. Гоголь, помня страшное время в Украине, написал об этом «Страшную месть». Лермонтов дал заветы поисковому россиеведению.

Более двух тысячелетий тому назад св. апостол Андрей Первозванный оповестил жителей Восточной Европы об учении Иисуса Христа. Цивилизационная стрела времени пронзила коллективную душу общерусского народа и дала возможность в едином создать три нации - россиян, украинцев и белорусов. Мы теперь «другие» европейцы. Смыслы и цели остаются, а не улетучиваются. Петр I и Екатерина II воплощают собою общерусскую субъективность и российскую государственность. Их пример воодушевляет нас на то, чтобы «перевыполнять законы» (В. Черномырдин).

Нам, духовным потомкам св. ап. Андрея Первозванного, переданы иные ключи от Христа и русская мечта, которую Гоголь назвал «птицей-тройкой». Классики понимали мечтательную религиозность как переживание высших ценностей, особенно ценя индивидуализм, соборность, правду и справедливость. У них мы можем научиться умению быть снисходительными к деятелям и деяниям.

Восточная общерусская ключимость как ее качественность и совокупность свойств супернарода обладает, наряду с общим с западным христианством, самобытной исторической спецификой - православием и оригинальной культурой. Западноевропейский рыцарь назван Пушкиным Скупым рыцарем. Он спускался в свои подвалы, открывал драгоценные сундуки, чтобы полюбоваться блеском хранимого там золота. Скупой рыцарь наслаждался сознанием того, что он - обладатель накопленных в этих сундуках богатств. Примером рыцаря должны воспользоваться современные правители. Под мудрым водительством народ формирует свою богатую культуру.

В отличие от Скупого рыцаря, великороссы, малороссы и белорусы много веков пополняли содержимое в своих сундуках, чувствуя опасность эгоизма и корыстолюбия.

Русское простонародье вводит в житейский обиход Ивана-дурака. О нем писатель А.Д. Синявский написал интересное исследование, посвященное русской народной вере. Она рассчитывает прежде всего на, так сказать, щучье веление в сочетании с человеческим хотением.

Классики действуют во всемирной информационно-энергетической системе. В ее центр человечество ставит личность Богочеловека и по Его примеру думающего и нравственного человека. Он способен думать о совокупности законов бытия, которую В.О. Ключевский называл Богом. В моем понимании речь идет о Всемирной информационно-энергетической системе. Философы считают, что в ее центре находится познающий и действующий субъект. Ему представляется мир в виде взаимосвязанных противоположностей: свобода - необходимость, добро - зло, господство - подчинение. «Разруливая» эти понятия, народ признает в своем гласе «глас Божий».

\section{Посмертная жизнь интеллекта}

Мысли и люди вместе не уходят, хотя живут под вопросом времени. Время жизни человека заключается в том, чтобы обдумывать смысл своего существования. Блез Паскаль имел основание сказать: «Мы никогда не живем, а располагаем жить».

Я думаю, что русские классики не только располагали своей жизнью, нередко краткой, как у Пушкина и Лермонтова, но и жили в высшей степени душевно и духовно.

А.С. Пушкин... Для него были дивно близки два чувства: «любовь к родному 
пепелищу», «любовь к отеческим гробам». Пушкинское «наше все» содержит в себе идеи свободы, истины, добра и красоты. Своими предсмертными словами: «Выше! Выше!» гений завещал России историческое восхождение. В нем концентрированно выражается человеческая способность мыслить, критически относиться к реальности, чтобы принимать ответственные решения.

М.Ю. Лермонтов... Моя жизнь, начавшись в Пятигорске, связана с памятью о нем и с освоением его душевно-духовного богатства. Более всего поэт-мыслитель любил «Родину» и «Бородино». Уезжая на Кавказ, он сказал: «Прощай, немотная Россия...» (именно так в оригинале). То, что мы называем дуэлью, было лермонтовским самопожертвованием во имя ближнего и дальнего. Своим заявлением: «Я - Бог..» Лермонтов оставил нам видение антропоцентрической картины мира. Лермонтовская идеократость обусловлена столкновением передовых идей с реакционным режимом.

Н.В. Гоголь... Идеократость Пушкина и Лермонтова сочетается с идеократостью Гоголя - изоморфа общерусскости. Он выразил житейскую мудрость русского народа в единстве великороссов и малороссов. Гоголь ворвался со своей правдой сквозь благодетельный обман «Ревизора». Он мечтал о том, чтобы «Мертвые души» стали живыми душами предпринимательства. Последнее рождало опасение: «Куда ты несешься, Русь?» В наши дни особо актуальны гоголевское учение о жизненном пути и сакральный взгляд Бориса Пастернака («Доктор Живаго») на отечественную революционность. Она вдохновляется идеократостью Христа.

Великий писатель и мыслитель Ф.М. Достоевский искал в русской культуре Бога и боролся с ним с догматической страстью. Он надеялся обрести окончательное решение истины, вовлекаясь в вечную душевную борьбу Бога и дьявола. Достоевский нам дорог учением о религиозном призвании России, осуществляющей идею нации как соборной индивидуальности. Происходит это в борьбе с «бесами» в образе воинствующих атеистов.

Мне кажется, что хотя Ленин и Сталин не верили в Бога, но иногда я предполагаю, что Бог верил в них и в то, что большевизм создал великую державу Справедливости. Нам остается лишь сожалеть, что партийная геронтократия свела СССР в могилу. Слава Богу, я, бывший коммунист, не был атеистом. Считаю, что существующее идет к разуму и добру.

Л.Н.Толстой... Гениальная идеократость осуществлена им. Он - громадное явление культуры, в которой противоборствуют Добро и Красота. Он сказал: «Чем больше мы отдаемся красоте, тем больше удаляемся от добра». Постигая красоту, он обращался к Богу - Природе. Почитая духовную или нравственную красоту, Лев Толстой разумел «не что иное, как добро».

Толстовская идеократость включает в себя социальные идеи, которые делали его великим революционером по отношению к существующему обществу и государству. Он отрицал всякую принудительную власть и всякое насилие. Конечно же, толстовский анархизм не может быть принят нами. Государство есть организм и тело России, которые требуют своего единства и целостности.

В современную идеократость должна войти толстовская идея ответственности человека за себя и за мир. Большое значение властвования дает повод подчеркнуть глубокий смысл и культурную ценность моральной проповеди Льва Толстого. Она может принести громадную пользу, поскольку послужит делу практического оздоровления общественного мнения, которое в настоящее время серьезно больно эгоизмом, отсутствием религиозного направления мыслей.

Главная причина, позволяющая очень высоко оценивать властвование идей В.С. Соловьева, заключается в их несомненной актуальности. Для великого 
мыслителя главным был вопрос: «Быть или не быть Правде на земле?» Он обращен к деятельной воле, жизненной цели, направлен на погашение всяческой вражды.

В наше время обсуждаются поставленные В.С. Соловьевым проблемы: о праве и нравственности, о христианско-правовом государстве. Он отстаивал сущность права, доказывал силу права против права силы. Правовое государство не было для Соловьева окончательным вариантом воплощения человеческой солидарности, а только ступенью к высшей форме межличностного общения. Право свободы, по Соловьеву, основано на самом существе человека и должно быть обеспечено извне государством. Самостоятельность личности определяется ее «разумом, волей и своеобразным характером». Она имеет безусловное достоинство, ибо «личность есть сосредоточенное или сжатое общество», а общество «есть расширенная, или восполненная личность».

Patriotica П.Б. Струве... Она представлена в объемистой книге ${ }^{1}$. Струве - разработчик идей «великой России» и концепции либерального консерватизма. Внимание Петра Бернардовича было акцентировано на проблемах отечественной государственности, гражданственности и духовности. Он высказал мысли о судьбе России и о месте страны во всемирной истории. В наши дни с интересом воспринимаются суждения П. Струве об истоках и смысле российской революции. Он рассмотрел роль национальной культуры и правосознания в российском прогрессе.

В начале XX в. Россия, по мнению Струве, превращается в «неестественный режим». Общество взбудоражила «революционно-провокационная феерия». Террористы держали власть в страхе; она была отчуждена и отрезана от общества. Вместо идеи воспитания народа в политике утверждался деспотизм. П.Б. Струве, не являясь служителем какого-либо «направления идей», выступил за духовную свободу, за служение Родине и Благу.

Рассмотренный сюжет видит в классиках творцов истории сослагательного наклонения. Поэты писали ее стихами. Историческую ткань вырабатывали их мысли, поступки, политические взгляды.

\section{Классика революционной эволюции}

Поиск истины перевернул мое представление о революции 1917. Я не понимал череду идеократости Сергея Есенина, Марины Цветаевой, Александра Блока и Федора Степуна. Достойно сожаления и то, что о ней общественность не вспомнила в 2017 г., спустя столетие после Великой пацифистской революции (март-декабрь 1917 г.).

Первым принял идею христианского миролюбия С.А. Есенин, который «пошел» встречать «дорогого гостя». Им был Иисус Христос, с образом которого поэт жил с детства до своего смертного часа.

Весной 1917 г. Есенин впервые принимает космическую информацию. Его поэма «Певущий зов» оповестила всех о тетраде глаголов, услышанных Есениным: постигать, мерить, любить, верить. Кто-то мудрый, несказанный, / Все себе подобя, / Всех живущих греет песней, / Мертвых - сном во гробе.

В есенинской поэзии мы слышим пророка, обладающего способностью говорить языком библейских пророков. Есенин предложил свое понимание многообразия жизни. Но ее одолел в XX в. воинствующий материализм и атеизм, определивший практику большевизма. В XXI в. вновь зазвучит есенинская идеократость патриотизма, четыре сакральных глагола.

Великий поэт-мыслитель М.И. Цветаева удовлетворяла личное любопытство

\footnotetext{
${ }^{1}$ Струве П.Б. Patriotica: Политика, культура, религия, социализм. М.: Республика. 1997. 527 с.
} 
не за государственный, а за свой скромный счет. Цветаевские поэзия и наука это гениальное «Я».

Семнадцатилетняя Марина Цветаева написала надгробную надпись над могилой Российской империи, до гибели которой оставалось около шести лет. Ее правильные представления подтверждаются историей того, чего уже нет и не будет. История «Под землей» - это философия настоящего и будущего. Меня радует союз между ушедшими, пришедшими и приходящими. Хорошо, что ежегодно идет «Бессмертный полк».

Мне представляется исключительно ценным взгляд М. Цветаевой на революцию 1917 г. Она отметила неправоту царя: он вверг страну в мировое побоище, ставшее «кощунством над человеком и природой» (В.В. Маяковский).

Идею революционного пацифизма обосновал философ Федор Степун. Я разделяю его правильную идеократость. Он видит революционную силу в народной инициативе, причем понятие «народ» соответствует понятию «нация», а не марксистскому понятию «пролетариат». Идеократость Ф. Степуна можно представить по его книгам «Бывшее и несбывшееся» и «Встречи». Мы узнаем о том, что Россия упустила свою историческую судьбу; она могла не вступать в мировую войну и избежать трагедии своей культуры.

Степун заметил, что Блок и Зайцев близко подходят к вере, что революция в своих бессознательных глубинах чем-то связана с Христом. Его образ - во главе «Двенадцати» красногвардейцев. Классики указали на Христов символ грядущего возрождения России.

Русская классика, выступая за уничтожение института войны, объявила, по примеру Льва Толстого, узаконенное насилие вне закона. Первый премьерминистр Временного правительства князь Георгий Львов пытался осуществлять революцию в 1917 по Льву Толстому - без насилия. Но для Керенского и Ленина главным делом было революционное насилие.

Классика революционной эволюции должна быть востребована нами. Негоже термин «революция» предавать анафеме, что проделывают неолибералы и неоконсерваторы. Путинский прорыв в будущее - это подлинность революционной эволюции.

Прорывной взлет в этом качестве совершила столетие назад великий мыслитель М.И. Цветаева. В цветаевской идеократости мы находим мысль о трех мирах: «Под землей», «На земле» и «Над землей». Приняв на себя роль судьи царизма, она вынесла вердикт об исторической его неправоте. Прожив три месяца в Отечественную войну, М.И. Цветаева решает свою жизнь матери детей отдать Родине-матери. Цветаевский нравственный подвиг сродни лермонтовскому. Два гения своей жизнью подтвердили истину: двигателем России является интеллектуальная деятельность и нравственный подвиг.

\section{Оговорился ли Путин по Фрейду?}

Категорическое отрицание этого вопрошания предполагает некоторую аргументацию. Сразу же должен признаться в том, что три года назад я решился на «диалог» с Владимиром Путиным не как с первым государственным мужем, а как с приемным сыном. Трое моих детей ушли в мир иной. Я, красноармеец в войну, чту память красноармейца Владимира Спиридоновича Путина. Нас пощадила война, он получил дар свыше. Отечественная история признает в нравственных подвигах свой двигатель.

Три года назад мне стало ясно, что трагический историзм России имеет сослагательное наклонение, которое познается философией истории вместе с ее видимым движением. Вовлеченный в нее М.Ю. Лермонтов прощался не с «немытой» Россией, а с немотной, лишенной гласности. Ни Александр I, ни 
Николай I не решились на отмену позорного крепостничества. Император Александр III Миротворец умер с надеждой, что его наследник не ввяжется в большую войну. Атеист В.И. Ленин и любящий Христа И.В. Сталин надеялись на избавление трудящихся всего мира от эксплуатации капиталом. В сталинском периоде россияне видят две трети хорошими, а треть - плохою.

Думая о В.В. Путине, я сопоставляю страницы книг профессоров ЛГУ, лекции которых он слушал. Огорчило услышанное из его уст словосочетание «немытая Россия». Но был несказанно обрадован, когда узнал из Интернета новость о праве истории на сослагательное наклонение. Соглашаясь с этим тезисом, можно предположить, что история кого-то чему-то научила.

Действительно, В.В. Путин правильно рассуждал об истории и политике. Уверен, что у него была продуманная заготовка касательно истории. В ней он видит власть, которая приносит благодеяния.

Заявляю о решительном отказе от ошибочной догмы: «история не терпит сослагательного наклонения». Священная история многострадальной России раскрывается не только в деяниях народа и власти, но и в религиозных особах, в сакральных обстоятельствах и мистических событиях. Их историческим примером является «второе крещение» Руси - России - СССР в 1988 г.

Сакральное движение наблюдается в узловых пунктах истории, а оживленные движения часто наблюдаются «в тупиках истории» (словоупотребление Арнольда Тойнби). Именно тогда часами истории распоряжаются правители в роли часовщиков. И события подтверждают тогда едкое изречение Джона Стейнбека, что история есть продукт выделений желез миллиона историков. Так, к примеру, многие современные историки и политики стали толковать российскую революцию 1917 г. как нецелесообразный хаос. Они не поняли того, что на завершающей фазе Первой мировой войны поднялось многомиллионное движение всероссийского народа в целях свержения прогнившей власти и выбора Учредительного собрания.

Общепринятыми в среде религиозных людей считаются вера в Бога (надо верить), необходимость молитвы (надо молиться) и признание чуда (надо верить в чудеса). Ибо, как спрашивал апостол Павел, «если Бог за нас, кто против нас?» (Рим. 8: 31). Наперекор этому вопросу многие считают, что, признавая Бога, можно в него не верить. Они спорят с Вольтером, сказавшим: «Верить в Бога невозможно, не верить в него - абсурдно». Правда позволила В.В. Путину не оговориться, а высказаться по существу политики и истории.

Итак, история сослагательного наклонения является жизнью идей целого и блага: она есть идеократство гениальных мыслителей. Они сознавали себя абсолютным началом: «Я - бог...» Реализуемые гениями цели и задачи имели в виду эмпирическую государственно-общественную жизнь. Последняя - предмет научной истории, которая учитывает два земных «божества» - общество и личность. Над роковым конфликтом между ними «парят» святыни Родины, Правды, Блага.

История сослагательного наклонения повествует о жизни, которую классики хотели бы прожить вместе с обществом. С. Есенин, А. Блок и А. Белый возвестили миру о Втором пришествии Христа. Представленный ими образ обладает огромной притягательной силой, которая раскрылась в мировые войны как жажда человечности. Утолить эту жажду стремился революционный пацифизм 1917 г. Через четыре десятилетия Борис Пастернак в знаменитом романе «Доктор Живаго» персонифицировал в образе Христа миролюбие и гуманизм. Торжество христианства явилось историческим примером сослагательного наклонения vs партийный атеизм.

Откровение потребовало от главы России в исторический миг трагедии 
«Дубровки» встать на колени пред образом Богоматери. Мольба Владимира Путина о спасении жизни соотечественников - убедительное доказательство пересечения в текущей российской истории двух наклонений. Наша история имеет сакральный характер: два лика транслируют требования об осуществлении Россией тех или иных целей и задач.

И.В. Сталину пришлось действовать на стыке двух эпох, ему трудно было разделаться со старой культурой и моралью. Он не признал поэтому историю сослагательного наклонения. Стоит вспомнить по этому поводу беседу с писателем Эмилем Людвигом.

На стыке двух эпох успешно действует В.В. Путин, который вырос при советской власти. Ему нелегко разделаться с негативом социализма и очень трудно вести «социалистический капитализм» по революционному пути эволюции. Делать это нельзя без признания пластов истории - на земле, под землей и над землей. Президент не может изменить прошлое, но философы, историки, социологи могут помочь ему в познании минувшего, в котором созревает грядущее.

Будущее созревает в отечественной истории двух ликов, двух наклонений. С болью и гордостью за прошлое родной страны ее классики пересматривают старые ценности и творчески овладевают новыми: подключаясь к ВИЭС, гении информируют общество о новом пути к лучшему будущему. «Революционная эволюция» - так называется эта дорога. Она требует разработки следующих словосочетаний:

1) «всероссийская солидарность», разрешающая противоречие между индивидуальным и государственным;

2) «революционная эволюция», синтезирующая категории «революция» и «эволюция»;

3) «самодержавный народ», ведомый не партиями, а полновластным государем - главой России и лидером нации.

Владычество классиков как современное просвещение является развенчанием «демократических» суеверий, которые препятствуют революционному повороту в России. Мне остается надеяться на признание этого научно-философского утверждения.

\section{IDEOCRACY OF CLASSICS: WHAT HISTORY DOES IT CREATE?}

\footnotetext{
Abstract. The article is a philosophical understanding of the history of Russia, the recognition of the power of ideas ideocracy, which is based on religious and cultural foundations and is presented in the heritage of the classics of literature and philosophy. The author consistently develops the atropy principle, putting forward the idea of naming the Higher Power as the World Energy Information System (WEIS), connecting substance, force, spirit. The author calls the terms of the new path to a better future a revolutionary evolution - this is the name of this road.

Keywords: history, philosophy of history, subjunctive in history, ideocracy, classics, reasoning citizen, revolution, revolutionary evolution
} 